\title{
Age-specific survival analysis of an infaunal meiobenthic harpacticoid copepod, Amphiascus tenuiremis
}

\author{
Andrew S. Green ${ }^{1, *}$, G. Thomas Chandler ${ }^{1,2}$, Bruce C. Coull ${ }^{2}$ \\ ${ }^{1}$ Department of Environmental Health Sciences, School of Public Health, ${ }^{2}$ Marine Science Program, \\ University of South Carolina, Columbia, South Carolina 29208, USA
}

\begin{abstract}
Survival analysis was used to calculate age-specific life expectancy $\left(e_{x}\right)$ for the benthic harpacticoid copepod Amphiascus tenuiremis Mielke, 1974. Gravid females were collected and held in brooding chambers to produce nauplii for the experiment. A cohort of 110 one-day-old nauplii was sampled on a weekly basis for survival and fecundity data until all of the original cohort members had died. Survival data was then used in an abridged life table to calculate life expectancy. Mortality in the cohort was extremely high during the first 2 wk of life with only $57 \%$ surviving to Week 3 . Life expectancy for a newborn nauplius was $5.4 \mathrm{wk}$ while a copepod surviving for $2 \mathrm{wk}$ could be expected to live an additional $6.9 \mathrm{wk}$. Maximum longevity observed in the cohort was $21.5 \mathrm{wk}$.
\end{abstract}

KEY WORDS: Copepod Harpacticoid S Survival analysis Life expectancy

\section{INTRODUCTION}

Population dynamics has been the subject of many investigations with harpacticoid copepods (D'Apolito \& Stancyk 1979, Palmer 1980, Palmer \& Coull 1980; for review, see Hicks \& Coull 1983, Webb \& Parsons 1988, Morris \& Coull 1992, Woods \& Coull 1992). Survival and reproduction data have been used to construct life tables giving intrinsic rates of increase, net reproductive rates, as well as other population parameters (Walker 1979, Bergmans 1981, Lonsdale 1981, Nilsson 1987, Miliou \& Moraitou-Apostolopoulou 1991). Despite this considerable amount of life history data, few studies have utilized survival analysis to provide critical population dynamics information. In addition, most of the referenced life table work has been conducted with epibenthic/semi-pelagic species, e.g. Tisbe spp., Coullana spp. Few, if any, studies have characterized lifetime survivorship for holobenthic, sediment-dwelling species because of logistical difficulties with sediment-substrate culture.

•E-mail:agreen@univscrm.sc.edu
Amphiascus tenuiremis cf. Mielke, 1974 is a far-ranging, infaunal mud-dwelling harpacticoid copepod that has been successfully cultured continuously (Chandler 1986) in sediments in our laboratory since 1988. It has a life history typical of most harpacticoids with 6 naupliar and 6 copepodite stages, the sixth copepodite stage being the sexually mature adult. Because of its ease of culture, A. tenuiremis has been utilized in several sediment toxicity studies (Strawbridge et al. 1992, Green et al. 1993, Chandler et al. 1994, Green \& Chandler 1994). However, little is known about its population dynamics including basic mortality and reproductive information, which would aid in the understanding of these and similar studies. For most sediment-dwelling copepod species, life history studies have been limited to fixed field population surveys (Morris \& Coull 1992), but the culturability of $A$. tenuiremis allows accurate determinations of age-specific population parameters under controlled conditions.

The purpose of this study was to (1) culture a cohort of newborn nauplii through their life span and collect age-specific mortality and fecundity data and (2) use survival analysis to calculate age-specific life expectancies $\left(e_{x}\right)$ from survival rates $\left(l_{x}\right)$. 


\section{MATERIALS AND METHODS}

Preparation of sediment substratum. Oxidized surface sediments ( 0 to $3 \mathrm{~cm}$ ) were collected from Bread and Butter Creek, North Inlet, South Carolina, USA $\left(33^{\circ} 20^{\prime} \mathrm{N}, 79^{\circ} 10^{\prime} \mathrm{W}\right)$, sieved through a $63 \mu \mathrm{m}$ sieve and cleansed/condensed as described by Chandler (1986). On a weekly basis throughout the duration of the experiment, autoclaved stock sediments were blended with aerated artificial seawater (30 ppt) and sieved on a $40 \mu \mathrm{m}$ sieve. The resulting mixture was then mixed with $4 \mathrm{l}$ of aerated artificial seawater and allowed to re-sediment for $24 \mathrm{~h}$ at $4^{\circ} \mathrm{C}$. The supernatant was then removed via aspiration leaving sediment ready for use. Sediment organic content was $3.8 \%$ (by CHN analysis) and solids content (dry weight) was $13 \%$. Median grain size determined by a Coulter Multisizer II was $2.5 \pm 1.1 \mu \mathrm{m}$

Organisms. Study copepods were obtained from flow-through sediment microcosm cultures of monospecific Amphiascus tenuiremis stocks (Chandler 1986). Cultures were fed twice a week with a mixed diet of the unicellular algae Isochrysis galbana Haines, Dunaliella tertiolecta Butcher, and Phaeodactylum tricornutum Bohlin. Three days prior to initiation of the experiment, approximately 200 gravid females were harvested from $2 \mathrm{l}$ culture dishes by aspirating 50 to $100 \mathrm{ml}$ of the upper sediment layer from each culture dish. Sediments and organisms were then sieved through a $125 \mu \mathrm{m}$ sieve. Material retained on the screen was washed into a Petri dish where organisms were sorted live under a Nikon SMZ-U stereo microscope. Gravid females were pipetted into a $250 \mathrm{ml}$ Petri dish brood chamber filled with sediment, seawater, and food. The brood chamber was incubated at $20^{\circ} \mathrm{C}$ on a $12 \mathrm{~h}$ light $.12 \mathrm{~h}$ dark cycle for $24 \mathrm{~h}$, at which time the contents of the dish were sieved through a $125 \mu \mathrm{m}$ and $40 \mu \mathrm{m}$ sieve. Contents retained on the $40 \mu \mathrm{m}$ sieve were then sorted under a stereo microscope and nauplii counted and pipetted into a new Petri dish with sediment and seawater where they were held until initiation of the experiment. This naupliar cohort used in the life history experiment was therefore composed of nauplii hatched within a 0 to 24 h time span.

Experimental design. Eleven replicate culture chambers with 10 nauplii in each replicate were established. Experimental chambers (10 $\mathrm{ml}$ Petri dishes) were filled with $5 \mathrm{ml}$ of artificial (Instant Ocean), aerated, sterilefiltered seawater followed by $1 \mathrm{ml}$ of prepared sediment using a $5 \mathrm{ml}$ Finnpipette. Ten nauplii were added to each dish, and all dishes were placed in a humidified tray and held in an incubator at $20^{\circ} \mathrm{C}$ on a $12 \mathrm{~h}$ light $12 \mathrm{~h}$ dark cycle. Dishes received $200 \mu \mathrm{l}$ of concentrated mixed algae every other day for the duration of the experiment. To ensure water quality, $50 \%$ of the seawater was replaced with aerated seawater $96 \mathrm{~h}$ after initiation of the experiment. Dissolved oxygen, temperature, and salinity were measured from the exchanged water which was pooled from all dishes to provide adequate volume for measurements. All dishes were sieved on a $40 \mu \mathrm{m}$ sieve $7 \mathrm{~d}$ after initiation, and retained contents sorted under a stereo microscope for live copepods. Surviving copepods were then pipetted to newly prepared dishes after their specific life stage had been identified and recorded. All adult females produced were placed individually into dishes so that female specific fecundity could be followed. The procedure above was repeated on a weekly basis until all of the original cohort members had died, i.e. 22 wk. Due to the skewed (male dominant) sex ratio observed in this cohort of cultured Amphiascus tenuiremis, there were insufficient fecundity data recorded $(n=4)$ for a statistically reliable calculation of a full life table with the instantaneous rate of population increase $(r)$.

Expectation of life $\left(e_{x}\right)$ for Amphiascus tenuiremis was calculated in an abridged life table from the following (Carey 1993):

$$
e_{x}=T_{x} / l_{x}
$$

where $T_{x}$ is the total number of days lived beyond age $x$, and $I_{x}$ is the probability of surviving to age $x$. Supporting calculations are as follows: $T_{x}=\sum_{x}^{\infty}{ }_{n} L_{x}$ where ${ }_{n} L_{x}$ is per capita fraction of the time lived in the age interval $x$ to $x+n, n$ is the duration of the age interval, i.e. $7 \mathrm{~d}$ or $1 \mathrm{wk}_{i_{n}} L_{x}=n\left(I_{x}-0.5 d_{x}\right) ;{ }_{n} d_{x}$ (fraction of $I_{x}$ that die in interval $x$ to $x+n)=l_{x}-I_{x+1} i_{n} q_{x}$ (proportion alive at age $x$ that die through $x$ to $x+n)=1-{ }_{n} p_{x i}$ and ${ }_{n} p_{x}$ (proportion alive at age $x$ that survive through $x$ to $x+$ n) $=l_{x+1} / l_{x}$

\section{RESULTS}

The following values represent the average of the physico-chemical measurements $( \pm 1 \mathrm{SD})$ taken for water quality in the experiment: salinity $=31 \pm 1 \mathrm{ppt}$; temperature $=20.5 \pm 0.3^{\circ} \mathrm{C}$; and dissolved oxygen $=7.0$ $\pm 0.3 \mathrm{mg} \mathrm{l}^{-1}$.

The survivorship schedule $\left(l_{x}\right)$ for a 1 -d-old naupliar cohort of Amphiascus tenuiremis is given in Fig 1. The longest-lived individuals survived for $21.5 \mathrm{wk}$ or $151 \mathrm{~d}$ assuming mortality occurs halfway through a time interval. Highest mortality $(29.9 \%)$ occurred during the first week or naupliar stage. Mortality then became more linear as it decreased over the weekly intervals. The final 3 wk were represented by only 2 adult males. Mortality rates for the $22 \mathrm{wk}$ were used in an abridged life table to calculate life expectancy $\left(e_{x}\right)$ at age $x$ (Table 1 ).

Of the organisms surviving to Week 1, 74 (98.7\%) were nauplii; only 1 copepodite was found. After Week 


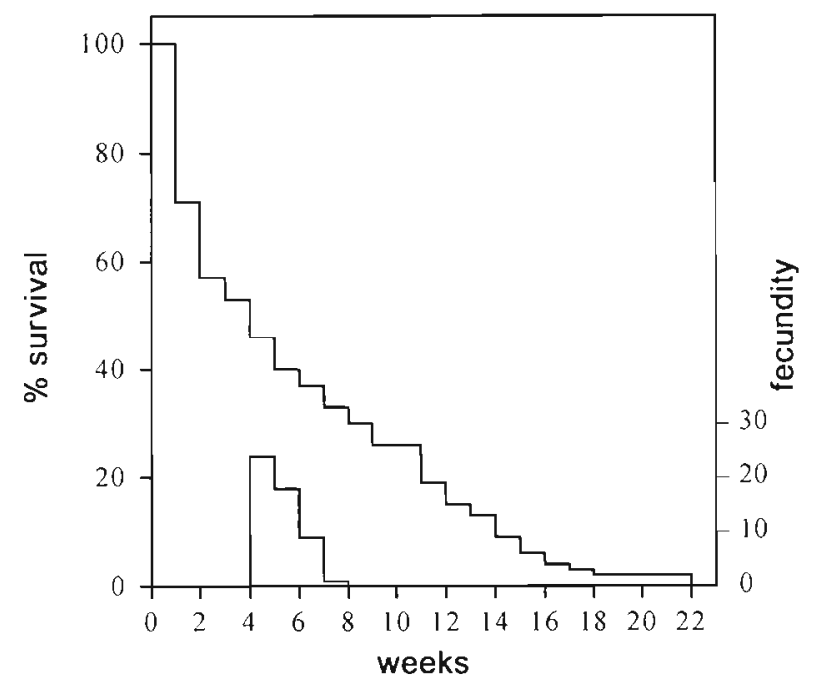

Fig. 1. Amphiascus tenuiremis. Age-specific survival and fecundity from Day 1 through 22 wk for naupliar cohort. Fecundity represents the average number of nauplii produced by 4 females

2, 62 copepodites made up $98.4 \%$ of surviving organisms and only 1 nauplius was found. By Week 3 only 2 copepodites were found; 56 adults comprised the rest of the cohort. Observed generation time (egg to egg) in the cohort was $22 \mathrm{~d}$ (assuming hatching occurred halfway through the time interval) while maturation from egg to adult required $21 \mathrm{~d}$. Sex ratio in the cohort was greatly skewed towards males with 5 females representing only $9 \%$ of the cohort. All 5 adult females found at Week 3 were gravid, with no reproduction occurring up to that point (Fig. 1). The longest period any female was able to produce offspring was $4 \mathrm{wk}$. After this, gravid females were still found, but eggs did not hatch and no naupliar production occurred. Lifetime production for 4 of the 5 females was $48.5 \pm 31.4$ (1 SD) offspring per female. The other Week 3 gravid female died in Week 4 and produced no offspring.

\section{DISCUSSION}

Based on survival analysis, life expectancy $\left(e_{x}\right)$ for newborn Amphiascus tenuiremis nauplii is $5.4 \mathrm{wk}$ whereas nauplii surviving past the first week are expected to live for an additional $6.4 \mathrm{wk}$. Life expectancy continues to increase up to a maximum of $6.9 \mathrm{wk}$ for individuals entering their third week of life. This is due primarily to the high mortality experienced in the first 2 wh in which only $53 \pm 19.5 \%$ (1 SD across replicates) of the cohort survives to Week 3 (Table 1). Life

Table 1. Amphiascus tenuiremis. Abridged life table showing survival rates, survival functions, and life expectancy for cohort of 110 one-day-old nauplii (table format and calculations from Carey 1993). See 'Materials and methods: Experimental design' for equation and supporting calculations

\begin{tabular}{|c|c|c|c|c|c|c|c|}
\hline $\begin{array}{l}\text { Age class } \\
\text { (wk) }\end{array}$ & $\begin{array}{c}\text { Fraction alive } \\
\text { at age } x\end{array}$ & $\begin{array}{l}\text { Proportion alive at } \\
\text { age } x \text { that survive } \\
\text { through } x \text { to } x+n\end{array}$ & $\begin{array}{l}\text { Proportion alive at } \\
\text { age } x \text { that die } \\
\text { through } x \text { to } x+n\end{array}$ & $\begin{array}{l}\text { Fraction of } l_{2} \\
\text { that die in } \\
\text { interval } x \text { to } x+n\end{array}$ & $\begin{array}{l}\text { Per capita fraction } \\
\text { of tume lived in } \\
\text { interval } x \text { to } x+n\end{array}$ & $\begin{array}{l}\text { Total no. of days } \\
\text { lived beyond } \\
\text { age } x\end{array}$ & $\begin{array}{l}\text { Expected no. of } \\
\text { additional weeks } \\
\text { individual will live }\end{array}$ \\
\hline$x$ & $l_{x}$ & $n p_{x}$ & ${ }_{n} q_{x}$ & ${ }_{n} d_{x}$ & ${ }_{n} L_{x}$ & $T_{x}$ & $e_{x}$ \\
\hline 0 & 1.000 & 0.709 & 0.291 & 0.291 & 5.982 & 37.991 & 5.4 \\
\hline 1 & 0.709 & 0.808 & 0.192 & 0.136 & 4.486 & 32.009 & 6.4 \\
\hline 2 & 0.573 & 0.921 & 0.079 & 0.045 & 3.850 & 27.523 & 6.9 \\
\hline 3 & 0.527 & 0.862 & 0.138 & 0.073 & 3.436 & 23.673 & 6.4 \\
\hline 4 & 0.455 & 0.880 & 0.120 & 0.055 & 2.991 & 20.236 & 6.4 \\
\hline 5 & 0.400 & 0.932 & 0.068 & 0.027 & 2.705 & 17.245 & 6.2 \\
\hline 6 & 0.373 & 0.878 & 0.122 & 0.045 & 2.450 & 14.541 & 5.6 \\
\hline 7 & 0.327 & 0.917 & 0.083 & 0.027 & 2.195 & 12.091 & 5.3 \\
\hline 8 & 0.300 & 0.879 & 0.121 & 0.036 & 1.973 & 9.895 & 4.7 \\
\hline 9 & 0.264 & 0.966 & 0.034 & 0.009 & 1.814 & 7.923 & 4.3 \\
\hline 10 & 0.255 & 0.750 & 0.250 & 0.064 & 1.559 & 6.109 & 3.4 \\
\hline 11 & 0.191 & 0.762 & 0.238 & 0.045 & 1.177 & 4.550 & 3.4 \\
\hline 12 & 0.145 & 0.875 & 0.125 & 0.018 & 0.955 & 3.373 & 3.3 \\
\hline 13 & 0.127 & 0.714 & 0.286 & 0.036 & 0.764 & 2.418 & 2.7 \\
\hline 14 & 0.091 & 0.600 & 0.400 & 0.036 & 0.509 & 1.655 & 2.6 \\
\hline 15 & 0.055 & 0.667 & 0.333 & 0.018 & 0.318 & 1.145 & 3.0 \\
\hline 1.6 & 0.036 & 0.750 & 0.250 & 0.009 & 0.223 & 0.827 & 3.3 \\
\hline 17 & 0.027 & 0.667 & 0.333 & 0.009 & 0.159 & 0.605 & 3.2 \\
\hline 18 & 0.018 & 1.000 & 0.000 & 0.000 & 0.127 & 0.445 & 3.5 \\
\hline 19 & 0.018 & 1.000 & 0.000 & 0.000 & 0.127 & 0.318 & 2.5 \\
\hline 20 & 0.018 & 1.000 & 0.000 & 0.000 & 0.127 & 0.191 & 1.5 \\
\hline 21 & 0.018 & 0.000 & 1.000 & 0.018 & 0.064 & 0.064 & 0.5 \\
\hline 22 & 0.000 & 0.000 & 0.000 & 0.000 & 0.000 & 0.000 & 0.0 \\
\hline
\end{tabular}


expectancy then decreases in a fairly consistent manner reaching median life expectancy at 10 to $12 \mathrm{wk}$ and zero life expectancy at $22 \mathrm{wk}$. Information like this can be used in conjunction with other population parameters to provide new insights into copepod population dynamics. Tatar et al. (1993) have suggested that agespecific mortality, the basis for life expectancy calculations, is the most appropriate demographic metric for evaluating changes in senescence in a population. Life expectancy data can also be used to help interpret and evaluate toxicity data. It allows the researcher to help differentiate between mortality being caused by age (natural causes) versus the toxicant being studied. This is especially true for early life-stage toxicity tests when sensitivity to extrinsic and intrinsic factors is greater. Fecundity data can be used with life expectancies to estimate the potential impact a newborn female can make to population growth relative to that of a female reaching reproductive maturity. For example, this study would predict that 10 newborn females would produce 288 progeny whereas 10 females surviving to Week 3 (adult stage) would produce 480 progeny. This assumes of course that $e_{x}$ holds true, 12 offspring $w^{-1}$ female ${ }^{-1}$ are produced, and reproduction occurs for $4 \mathrm{wk}$. In theory, a finer observational time-scale would yield more accurate life expectancy data, but, with mud-dwelling copepods, the work involved and potential stress to the organisms of more repetitive setups may not confer any advantages due to enhanced mortalities from handling stress.

The high naupliar mortality found for Amphiascus tenuiremis is almost half that predicted by field population models (Morris \& Coull 1992) for the epibenthic copepod Microarthridion littorale. Morris \& Coull (1992) predicted that naupliar mortality limits $M$. littorale population sizes because as much as $98 \%$ mortality would have to occur in the early life stages to maintain observed field population levels. They also suggested that the driving force behind naupliar mortality was juvenile fish predation. We found that, under optimal conditions, only $53 \%$ of the A. tenuiremis cohort survived to recruit into the adult stage. In the field, however, where competition and predation combine with the natural mortality, it is easy to imagine how extremely high (>90\%) early life-stage mortality rates could occur. Life expectancy data for $A$. tenuiremis mirror survival analysis on human populations where neonatal and infant mortality is high relative to other life stages, which in turn brings the overall life expectancy for humans down as well (Mausner \& Kramer 1985). As this is the only known benthic copepod study to use age-specific survival analysis to calculate life expectancy, direct comparisons with other harpacticoid species cannot be done. To allow for a crude comparison with harpacticoid species, life expectancy values for newborn nauplii were calculated from graphs of $I_{x}$ curves created in studies by Bergmans (1981) and Lonsdale (1981). An artificial time interval of $10 \mathrm{~d}$ was utilized so that survival data could be estimated from the graphs. This time step and survival data were then integrated in the abridged life table used in this study. Survival data for Tisbe furcata Baird gave life expectancy values of 53 and $61 \mathrm{~d}$ for females and males, respectively (Bergmans 1981). Survival data for Scottolana canadensis Willey (at 20 ppt salinity, $20^{\circ} \mathrm{C}$ ) gave a life expectancy value of $40 \mathrm{~d}$ for females. These values compare well with that found for A. tenuiremis ( $38 \mathrm{~d}$ ) in the present study, considering the differences in experimental conditions used and the crude derivation of data from graphs attempted here. The fact that $T$. furcata exhibits a considerably longer life expectancy is probably due to the extremely low mortality recorded for the cohort during the first 40 $\mathrm{d}$ of the study $\left(l_{x}>0.9\right)$. It should also be noted that the life expectancy value for $S$. canadensis is based on survival data from day of hatching through reproductivefemale stage and not through complete mortality for the cohort followed. Only one other meiofaunal laboratory study calculated life expectancy in a life table (Hummon 1974), but this was on a freshwater, meiofaunal gastrotrich (newborn life expectancy $=22.1 \mathrm{~d}$ ) so little comparison can be made. An indicator of life expectancy would be lifespan or longevity as it is a major factor in determining life expectancy, and this is a population parameter commonly recorded. Maximum longevity observed in this cohort of $A$. tenuiremis was 21.5 wk or $151 \mathrm{~d}$. This corresponds well with harpacticoid literature where the lifespan range from laboratory studies is between 12 and $400 \mathrm{~d}$ (see review, Hicks \& Coull 1983). Two laboratory studies using the closely related Amphiascoides sp. Willey and Amphiascoides subdebilis Willey found life spans of 160 and $114 \mathrm{~d}$ at temperatures of 23 and $24^{\circ} \mathrm{C}$ respectively (Walker 1979, Ingole 1994).

The observed skewed sex ratio of 11 males to 1 female was somewhat puzzling in its severe deviation from the expected 1:1. However, several studies have found similar deviations for harpacticoid populations where high density or inbreeding is prevalent (Hicks 1977, Charnov \& Bull 1977, Heip 1980, Soyer 1980, Bergmans 1981). For the Amphiascus tenuiremis culture from which this cohort was obtained, both factors are probably present since this population has been cultured in isolation for several years. However, other studies conducted in our laboratory with A. tenuiremis in which sex ratios were recorded revealed highly variable ratios ranging from $4.8: 1$ to $1: 5.6$ males to females respectively (A. S. Green unpubl.). Although a detailed study of changes in life history traits of the culture population with time has not been conducted, a study 
which predates the present one by 4 yr found a sex ratio of $1: 1.2$ males to females in the culture population (Woods \& Coull 1992). This ratio falls within the range of ratios found in the culture in recent months. Even with a sex ratio so male dominant, a population would not have a problem maintaining itself with the fecundity exhibited in this study (48.5 offspring female ${ }^{-1}$ ).

This first calculation of life expectancy $\left(e_{x}\right)$ for a benthic harpacticoid copepod is based on demography techniques commonly used with insect and human populations (Mausner \& Kramer 1985, Carey 1993). However, it has not been utilized with copepod populations even though the data required are routinely recorded in most life table studies. More common use of survival analysis would broaden our understanding of harpacticoid copepod population dynamics with little additional laboratory work and analysis. Harpacticoid copepods are now being used with increasing frequency for toxicological studies (Chandler 1990, Chandler \& Scott 1991, Coull \& Chandler 1992, Strawbridge et al. 1992, DiPinto et al. 1993, Green et al. 1993, Chandler et al. 1994, Green \& Chandler 1994) and as food for juvenile fish in aquaculture (Watanabe et al. 1983, Norsker \& Stottrup 1994). Understanding their population dynamics would add tremendously to their utility for these settings, as well as providing useful data for bioenergetic and community studies.

Acknowledgements. This research was supported by the U.S. Environmental Protection Agency, Office of Exploratory Research, Assistance No. R8170000-01 (B. C. Coull and G. T. Chandler, principal investigators) and by the U.S. National Oceanic and Atmospheric Administration Coastal Ocean Program. The authors thank T L. Donelan and T. Mitchell for help with copepod and algal cultures.

\section{LITERATURE CITED}

Bergmans M (1981) A demographic study of the life cycle of Tisbe furcata (Baird 1837) (Copepoda: Harpacticoida). J mar biol Ass UK 61:691-705

Carey JR (1993) Applied demography for biologists: with special emphasis on insects. Oxford University Press, New York

Chandler GT (1986) High-density culture of meiobenthic harpacticoid copepods within a muddy sediment substrate. Can J Fish Aquat Sci 43:53-59

Chandler GT (1990) Effects of sediment-bound residues of the pyrethroid insecticide fenvalerate on survival and reproduction of meiobenthic copepods. Mar environ Res 29: $65-76$

Chandler GT, Coull BC, Davis JC (1994) Sediment- and aqueous-phase fenvalerate effects on meiobenthos: implications for sediment quality criteria development. Mar environ $\operatorname{Res} 37: 313-327$

Chandler GT, Scott GI (1991) Effects of sediment-bound endosulfan on survival, reproduction and larval settlement of meiobenthic polychaetes and copepods. Environ Toxicol Chem 10:375-382
Charnov EL, Bull J (1977) When is sex environmentally determined. Nature 266:288-290

Coull BC, Chandler GT (1992) Pollution and meiofauna: field, laboratory, and mesocosm studies. Oceanogr mar biol $\mathrm{A}$ Rev 30:191-271

D'Apolito LM, Stancyk SE (1979) Population dynamics of Euterina acutifrons (Copepoda: Harpacticoida) from North Inlet, South Carolina, with reference to dimorphic males. Mar Biol 54:251-260

DiPinto LM, Coull BC, Chandler GT (1993) Lethal and sublethal effects of the sediment-associated PCB Aroclor 1254 on a meiobenthic copepod. Environ Toxicol Chem 12: $1909-1918$

Green AS, Chandler GT (1994) Meiofaunal bioturbation effects on the partitioning of sediment-associated cadmium. J exp mar Biol Ecol 180:59-70

Green AS, Chandler GT, Blood ER (1993) Aqueous-, porewater-, and sediment-phase cadmium: toxicity relationships for a meiobenthic copepod. Environ Toxicol Chem 12:1497-1506

Heip C (1980) The influence of competition and predation on production of meiobenthic copepods. In: Tenore KR, Coull $\mathrm{BC}$ (eds) Marine benthic dynamics. University of South Carolina Press, Columbia, p 167-177

Hicks GR (1977) Breeding activity of marine phytal harpacticoid copepods from Cook Strait. NZ J mar Freshwat Res 11:645-666

Hicks GR, Coull BC (1983) The ecology of marine meiobenthic harpacticoid copepods. Oceanogr mar biol A Rev 21: $67-175$

Hummon WD (1974) Effects of DDT on longevity and reproductive rate in Lepidodermella squammata (Gastrotricha, Chaetonotida). Am Mid Nat 92:327-339

Ingole BS (1994) Influence of salinity on the reproductive potential of a laboratory cultured harpacticoid copepod, Amphiascoides subdebilis Willey, 1935. Zool Anz 232: $31-40$

Lonsdale DJ (1981) Influence of age-specific mortality on the life history traits of two estuarine copepods. Mar Ecol Prog Ser 5:333-340

Mausner JS, Kramer S (1985) Epidemiology: an introductory text. WB Saunders Company, Philadelphia

Miliou H, Moraitou-Apostolopoulou M (1991) Combined effects of temperature and salinity on the population dynamics of Tisbe holothuriae Humes (Copepoda: Harpacticoida). Arch Hydrobiol 121:431-448

Morris JT, Coull BC (1992) Population dynamics, numerical production, and potential predation impact on a meiobenthic copepod. Can J Fish Aquat Sci 49:609-616

Nilsson P (1987) Demography of Mesochra Lilljeborgi and Amonardia normani (Copepoda: Harpacticoida) reared on two diatom diets. Mar Ecol Prog Ser 39:267-274

Norsker N. Stottrup JG (1994) The importance of dietary HUFAs for fecundity and HUFA content in the harpacticoid, Tisbe holothuriae Humes. Aquaculture 125:155-166

Palmer MA. (1980) Variation in life-history patterns between intertidal and subtidal populations of the meiobenthic copepod Microarthridion littorale. Mar Biol 60:159-165

Palmer MA, Coull BC (1980) The prediction of development rate and the effect of temperature for the meiobenthic copepod, Microarthridion littorale (Poppe). J exp mar Biol Ecol 48:73-83

Soyer J (1980) Cycle biologique d'un copépode harpacticoide des vases terrigènes côtières de Banyuls-sur-Mer: Cletodes pusillus (Sars). Vie Milieu 30:35-44

Strawbridge S, Coull BC, Chandler GT (1992) Reproductive output of a meiobenthic copepod exposed to sediment- 
associated fenvalerate. Arch Environ Contam Toxicol 23: 295--300

Tatar M, Carey JR, Vaupel JW (1993) Long-term cost of reproduction with and without accelerated senescence in Callosobruchus maculatus: analysis of age-specific mortality. Evolution 47:1302-1312

Walker I (1979) Mechanisms of density-dependent population regulation in the marine copepod Amphiascoides sp. (Harpacticoida). Mar Ecol Prog Ser 1:209-221
Watanabe T, Kitajima C. Fujita S (1983) Nutritional values of live organisms used in Japan for mass propagation of fish: a review. Aquaculture 34:115-143

Webb DG, Parsons TR (1988) Empirical analysis of the effect of temperature on marine harpacticoid copepod development time Can J Zool 266:1376-1381

Woods RE, Coull BC (1992) Life history responses of Amphiascus tenuiremis (Copepoda. Harpacticoida) to mimicked predation. Mar Ecol Prog Ser 79:225-234

Manuscript first received: February 21, 1995 Revised version accepted: May 29, 1995 